\title{
Quality attributes of roasted Arabica coffee oil extracted by pressing: composition, antioxidant activity, sun protection factor and other physical and chemical parameters
}

\author{
ĐB.R. Böger ${ }^{\mathrm{a} \circledast}, \oplus$ A.L.B. Mori ${ }^{\mathrm{a}},{ }^{\oplus}$ M.C. Viegas ${ }^{\mathrm{b}}$ and ${ }^{\circledR}$ M.T. Benassi ${ }^{\mathrm{a}}$ \\ ${ }^{\text {a}}$ Department of Food Science and Technology, Universidade Estadual de Londrina, Rodovia Celso Garcia Cid (PR 445), Km 380, \\ 86057-970 Londrina, Brazil \\ ${ }^{b}$ Research \& Development, Companhia Iguacu de Café Solúvel, Rodovia Mello Peixoto (BR 369), Km 88, 86300-000, \\ Cornelio Procopio, Brazil \\ ${ }^{\bowtie}$ Corresponding author: brunaraquel12@gmail.com
}

Submitted: November 26, 2019; Accepted: February 03, 2020; Published online: March 03, 2021

\begin{abstract}
SUMMARY: This research reports a comprehensive characterization of the composition profile and physical and chemical characteristics of roasted Arabica coffee oil obtained by mechanical pressing. The oil presented a peroxide value of $3.21 \mathrm{meq} \cdot \mathrm{kg}^{-1} \mathrm{and}$ an acid value of $7.3 \mathrm{mg} \mathrm{KOH} \cdot \mathrm{g}^{-1}$. A higher proportion of unsaturated fatty acids (58\%), predominantly linoleic (L) and palmitic (P) acids, was observed; PLL and PLP were estimated as the main triacylglycerols. The oil was characterized by high contents in diterpenes and tocopherols (3720 and $913 \mathrm{mg} \cdot 100 \mathrm{~g}^{-1}$, respectively), the presence of caffeine and chlorogenic acids, as well as a high sun protection factor (9.7) and ABTS free radical-scavenging capacity (12.5 mg Trolox $\left.\cdot \mathrm{mL}^{-1}\right)$. Among the 35 volatile compounds studied, furfurythiol and pyrazines were the main components of the oil. These properties showed that roasted coffee oil has good potential for use in food and cosmetics.
\end{abstract}

KEYWORDS: Coffee Arabica; Diterpenes; Tocopherols; Volatile compounds

RESUMEN: Atributos de calidad del aceite de café Arábica tostado extraído por prensado: composición, actividad antioxidante, factor de protección solar y otros parámetros físicos y químicos. Esta investigación reporta una caracterización completa del perfil de composición y características físicas y químicas del aceite de café Arábica tostado obtenido por prensado mecánico. El aceite presentó un índice de peróxido de 3,21 meq $\mathrm{kg}^{-1}$ y un índice de acidez de 7,3 $\mathrm{mg} \mathrm{de} \mathrm{KOH} \cdot \mathrm{g}^{-1}$. Se observó una mayor proporción de ácidos grasos insaturados (58\%), ácido linoleico, (L) y palmítico (P); PLL y PLP se estimaron como los principales triacilgliceroles. El aceite se caracterizó por un alto contenido de diterpenos y tocoferoles (3720 y $913 \mathrm{mg} \cdot 100 \mathrm{~g}^{-1}$, respectivamente), la presencia de cafeína y ácidos clorogénicos, así como un alto factor de protección solar $(9,7)$ y capacidad de captación de radicales libres ABTS (12,5 mg de Trolox $\cdot \mathrm{mL}^{-1}$ ). Entre los 35 compuestos volátiles estudiados, el furfuritiol y las pirazinas fueron los componentes principales del aceite. Estas propiedades mostraron que el aceite de café tostado tiene un buen potencial para su uso en alimentos y cosméticos.

PALABRAS CLAVE: Café Arabica; Compuestos volátiles; Diterpenos; Tocoferoles

Citation/Cómo citar este artículo: Böger BR, Mori ALB, Viegas MC, Benassi MT. 2021. Quality attributes of roasted Arabica coffee oil extracted by pressing: composition, antioxidant activity, sun protection factor and other physical and chemical parameters. Grasas Aceites 72 (1), e394. https://doi.org/10.3989/gya.1144192

Copyright: (C2021 CSIC. This is an open-access article distributed under the terms of the Creative Commons Attribution 4.0 International (CC BY 4.0) License. 


\section{INTRODUCTION}

Coffee is one of the most popular beverages worldwide. In the past 10 years, global coffee production has grown at an average annual rate of around $2.6 \%$ from 140.16 million $60-\mathrm{kg}$ bags in $2010 / 11$ to an estimated 168.71 million $60-\mathrm{kg}$ bags in 2019/20. Brazil is the world's secondlargest coffee consumer. In addition to being the main producer (57 million in 2019/20), in 2019 Brazil was also the world's largest exporter (37.7 million up to November), and soluble coffee represented around $10 \%$ of this total (Ico, 2019).

The mechanical pressing of coffee beans, green (raw) or roasted, is the most common industrial methods for oil extraction in Brazil (Oliveira et al., 2005). Iy is eco-friendly, and does not require the use of any solvents. Roasted coffee oil is a coproduct of the soluble coffee industry, and can be obtained by pressing the roasted beans before extraction of the soluble coffee. The roasted coffee oil is applied as a food flavoring, while green coffee oil is used in cosmetic formulations due to its antioxidant, emollient and UV protection properties (Calligaris et al., 2009; Wagemaker et al., 2011; Hurtado-Benavides et al., 2016).

Lipids are among the most abundant coffee components, accounting for 3.2 to $11 \%$ of the total green beans and 8.6 to $17 \%$ of the roasted coffee. The increase in lipid content with the roasting process is due to losses in $\mathrm{CO}_{2}$, water vapor and volatile compounds, and the degradation of carbohydrates, amino acids, and chlorogenic acids (Budryn et al., 2012; Dias et al., 2014; Pacetti et al., 2015). Owing to their relatively high thermal stability, lipids protect aromatic compounds from degradation (Wagemaker et al., 2011). The lipid fraction contains the majority of the volatile compounds responsible for the aroma (Calligaris et al., 2009; Wagemaker et al., 2011; Hurtado-Benavides et al., 2016). It also contributes to coffee brew viscosity (Pacetti et al., 2015). Triacylglycerols are the main components of coffee oil (about $75 \%$ ), which also presents from 15 to $18 \%$ of the unsaponifiable matter (UM) (Speer and KöllingSpeer, 2006), composed of hydrocarbons, steroids, and tocopherols (Belitz et al., 2009). It has a high proportion of UM compared to other vegetable oils $(0.2-1.5 \%)$, such as soybean (from 0.6 to $1.2 \%$ ), olive (from 0.4 to $1.1 \%$ ), and sunflower (from 0.3 to $1.2 \%$ ) (Belitz et al., 2009).
Coffee oil composition varies with harvesting and post-harvest handling practices, bean origin and genetics (species and varieties), as well as roasting and extraction conditions (Pacetti et al., 2015). The literature reports some data on coffee oil from the Arabica and Robusta species, although the majority of them are related to green coffee - extracted with solvents or more sophisticated methods (such as supercritical extraction). In general, researches focus on specific classes of compounds, such as fatty acids and volatile compounds (Oliveira et al., 2005; Calligaris et al., 2009; Budryn et al., 2012; Getachew and Chun, 2016; Hurtado-Benavides et al., 2016; Raba et al., 2018). Less information is available on UM compounds -such as diterpenes and tocopherols- and on the presence of hydrosoluble components, which could be carried during pressing, such as caffeine and chlorogenic acids (González et al., 2001; Oliveira et al., 2014; Guercia et al., 2016; Bitencourt et al., 2018).

Regarding the physico-chemical characteristics, which are essential for technological use, some studies focus on quality indices such as the peroxide value (Turatti, 2001; Budryn et al., 2012; Getachew and Chun, 2016) and thermal properties (Calligaris et al., 2009; Budryn et al., 2012; Raba et al., 2018), generally correlating these parameters with the fatty acid profile.

Considering the interest and potential use of roasted coffee oil as a food ingredient as well as in the cosmetic area, where green coffee oil is more common nowadays, this study aimed to report a comprehensive characterization of the composition profile and properties of roasted Arabica coffee oil obtained by mechanical pressing.

\section{MATERIALS AND METHODS}

\subsection{Materials}

The coffee oil was supplied by Company Iguaçu Soluble Coffee (Cornélio Procópio, Brazil). Commercial dry Arabica coffee beans ( 4.5 to $5.0 \% \mathrm{w} / \mathrm{w}$ moisture) were medium roasted at $220{ }^{\circ} \mathrm{C}$ (air temperature) and 5 mbar for 10 to $12 \mathrm{~min}$. The extraction was carried out at room temperature by cold pressing in an oil expeller SCOTTECH ERT 50 (Scott Tech USA, USA); the coffee reached a maximum of $60{ }^{\circ} \mathrm{C}$ during the process. The efficiency of the extraction was around 5 to $6 \%$ of oil $(\mathrm{w} / \mathrm{w})$. The oil was kept in a freezer at $-22{ }^{\circ} \mathrm{C}$ until analysis. 


\subsubsection{Reagents and standards}

The HPLC-grade solvents were tert-butyl methyl ether (Acros Organics, USA), acetonitrile (Mallinckrodt Baker, USA), and methanol (Merck, Germany). The following reagents and analytical grade materials were also used: potassium hydroxide (Quimex, Brazil), ethanol 98\% (JTBaker, Mexico), sulfuric acid 95-97\% (Merck, Germany), hydrochloric acid (Quimex, Brazil), sodium hydroxide (Sigma-Aldrich, USA), Trolox (6-hydroxy-2,5,7,8-tetramethylchroman-2carboxylic acid) (Sigma-Aldrich, USA), acetic acid (Merck, Germany), ABTS (2,2-azino-bis-3ethylbenzothiazoline-6-sulfonic acid) (SigmaAldrich, USA), potassium persulfate (Anidrol, Brazil), ethyl acetate (Sigma-Aldrich, USA), sodium thiosulphate (Synth, Brazil),Wijs solution (Anidrol, Brazil), potassium iodide (Synth, Brazil), carbon tetrachloride (Dinâmica, Brazil) and chloroform (Synth, Brazil).The water used to prepare standards and solutions was obtained by a purification system Elga Purelab Option-Q (Veolia Water Technologies, France). Nylon membranes were applied for filtration of solvents (Millipore, USA) and samples $(0.22 \mu \mathrm{m})$ (Whatman, UK). Standards of 5-caffeoylquinic acid (5-CQA), caffeine, fatty acid methyl esters (FAME Mix C4-C24) and tocopherols $(\alpha, \beta, \gamma$, and $\delta$ ) (Sigma-Aldrich, USA), and cafestol and kahweol (Axxora, USA) were used. For the volatile profile, the following standards were used: 2-3-dimethylpyrazine, pyrazine, 4-methylthiazole, 2-isobutyl-3-methylpyrazine, 2,3-butanedione, 2,3-pentanedione, acetoin, benzyl alcohol, maltol, furaneol, furfuryl acetate, 3-methylbutanal, 2,5-dimethylpyrazine, pyridine, 2,6-dimethylpyrazine, 4,5-dimethylthiazole, 2-furfurylthiol, 2-acetylpyridine, vanillin, phenylethyl alcohol, 4-ethylguaiacol, 4-vinylguaiacol, cis-isoeugenol, isovaleric acid, methanethiol, dimethyldisulfite, acetic acid, propanoic acid, acetaldehyde, guaiacol, 2,3-diethyl-5-methylpyrazine, furfural, linalool, 2-isobutyl-3-methoxypyrazine and 2-acetyl-3,5dimethylpyrazine (Sigma Aldrich, USA).

\subsection{Physico-chemical analyses}

The acid, iodine, and peroxide values were determined according to AOCS (2014). The peroxide value was determined using titrator TitroLine easy (Schott, Germany) with a $0.1 \mathrm{~N}$ sodium thiosulphate solution; results were expressed as meq of peroxide $\mathrm{kg}^{-1}$. The iodine value was determined by the Wijs method using a $0.1 \mathrm{~N}$ sodium thiosulphate solution; results were expressed as $\mathrm{g}$ of $\mathrm{I}_{2} \cdot 100 \mathrm{~g}^{-1}$. The saponification value was determined by the fatty acid composition, and was expressed as $\mathrm{mg} \mathrm{KOH} \cdot \mathrm{g}^{-1}$. All analyses were performed in triplicate.

The moisture and volatile matter were determined in triplicate according to the AOCS (2014) and expressed as a percentage. The oil (5 g) was oven-dried with air circulation TE-394/1 (Tecnal, Brazil) at $130{ }^{\circ} \mathrm{C}$ for $2 \mathrm{~h}$.

The antioxidant capacity was estimated based on the ABTS free radical scavenging capacity as described by Corso et al., (2016). The $\mathrm{ABTS}^{+}$ solution was produced by reacting $7 \mathrm{mmol} \cdot \mathrm{L}^{-1}$ of a ABTS stock solution with $2.45 \mathrm{mmol} \cdot \mathrm{L}^{-1}$ of potassium persulfate solution; the mixture stood in the dark at room temperature for 12-16 h prior to use. The $\mathrm{ABTS}^{+}$solution was diluted with $5 \mathrm{mmol} \cdot \mathrm{L}^{-1}$ phosphate buffer ( $\mathrm{pH}$ 7.4) to an absorbance of $0.70 \pm 0.02$ at $730 \mathrm{~nm}$. Ethyl acetate (1:12) was used for dilution. After the addition of $10 \mu \mathrm{L}$ of the sample or standard Trolox in $4 \mathrm{~mL}$ of $\mathrm{ABTS}^{+}$solution diluted, $6 \mathrm{~min}$ was taken for reaction, and $730 \mathrm{~nm}$ readings were performed on a UV-visible Libra S22 spectrophotometer (Biochrom, UK). Quantification was performed using the 5-point analytical curve (in triplicate) with Trolox. The analysis was performed in duplicate, and the results were expressed as $\mathrm{mg}$ Trolox $\cdot \mathrm{mL}^{-1}$.

\subsection{Physical analysis}

The refractive index was determined, in triplicate, in a refractometer RM 40 (Mettler Toledo, USA) at $20^{\circ} \mathrm{C}$.

The density was determined by an electronic digital densimeter, model DMA-35 (Anton Paar, Austria) using $10 \mathrm{~mL}$ of coffee oil; the result was expressed as $\mathrm{g} \cdot \mathrm{mL}^{-1}$. The viscosity was evaluated in a Viscometer DV-II (Brookfield, USA) and expressed in mPas. The analyses were performed at $25^{\circ} \mathrm{C}$ in triplicate.

In order to determine the sun protection factor (SPF) in vitro, the oil was dissolved in ethyl alcohol at the concentration of $0.2 \mu \mathrm{L} \cdot \mathrm{mL}^{-1}$. Three-fold readings were performed in the range of 290 to $320 \mathrm{~nm}$ (in $5 \mathrm{~nm}$ increments) in a UVvisible spectrophotometer Libra S22. The absorbance was multiplied by the erythemal effect of the radiation at each wavelength (Table 1), and the sum of the values was multiplied by a 
correction factor (determined according to two sunscreens with known SPF), as described by Wagemaker et al., (2011) (Eq. 1).

TABLE 1. Normalized product function used for sun protection factor calculation.

\begin{tabular}{cc}
\hline Wavelength $(\mathbf{n m})$ & EEx I (normalized) ${ }^{\mathrm{a}}$ \\
\hline 290 & 0.0150 \\
295 & 0.0817 \\
300 & 0.2874 \\
305 & 0.3278 \\
310 & 0.1864 \\
315 & 0.0839 \\
320 & 0.0180 \\
\hline
\end{tabular}

${ }^{\mathrm{a} E E}(\lambda)=$ erythemal effect spectrum; I $(\lambda)=$ solar intensity spectrum.

$$
S P F=C F \cdot \sum_{290}^{320} E E(\lambda) \cdot \mathrm{I}(\lambda) \cdot \operatorname{Abs}(\lambda)
$$

Where:

$\mathrm{CF}=$ correction factor $(=10)$;

$\mathrm{EE}(\lambda)=$ erythemal effect spectrum;

$I(\lambda)=$ solar intensity spectrum;

Abs $(\lambda)=$ absorbance of the sunscreen product.

\subsection{Chemical composition}

\subsubsection{Fatty acids and triacylglycerols}

The hydrolysis and transesterification of the fatty acids were performed according to ISO method 5509, using $2 \mathrm{~mol} \cdot \mathrm{L}^{-1} \mathrm{NaOH}$ in methanol and $\mathrm{n}$-heptane, in triplicate. After separation, the phase containing $\mathrm{n}$-heptane and fatty acid methyl esters was stored in an amber vial at $-18{ }^{\circ} \mathrm{C}$ until analysis. Methyl esters of fatty acids were analyzed using CG Shimadzu 17A (Kyoto, Japan) equipped with a flame ionization detector and a CP SIL 88 capillary column $(100 \mathrm{~m} \times 0.25 \mathrm{~mm})$ (Agilent Technologies Inc., USA). The column temperature was programmed as follows: $65^{\circ} \mathrm{C}$ $(15 \mathrm{~min})$; raised at $10^{\circ} \mathrm{C} \cdot \mathrm{min}^{-1}$ until $165^{\circ} \mathrm{C}$ and held for $2 \mathrm{~min}$; raised at $4{ }^{\circ} \mathrm{C} \cdot \mathrm{min}^{-1}$ to $185^{\circ} \mathrm{C}$ and held for $8 \mathrm{~min}$; raised at $4{ }^{\circ} \mathrm{C} \cdot \mathrm{min}^{-1}$ to $235^{\circ} \mathrm{C}$ and held for $5 \mathrm{~min}$. The detector and injector were maintained at $260{ }^{\circ} \mathrm{C}$, using $1 / 100$ Split. The gas flow rate was $1.2 \mathrm{~mL} \cdot \mathrm{min}^{-1}$ for the carrier gas $\left(\mathrm{H}_{2}\right)$ and $30 \mathrm{~mL} \cdot \mathrm{min}^{-1}$ for make-up gas $\left(\mathrm{N}_{2}\right)$. Identification of the fatty acids was based on comparison with standards and the results were expressed as relative percentages of the fatty acids identified.

Oil composition in triacylglycerols (TAG) was estimated by software available in the Plataforma Lames (2019) based on the fatty acid profile. This method results in a large number of TAGs, and in order to reduce the number of components, all structural isomers were divided into a set of components with the same number of carbon and double bonds. Each set of isomers was named according to the major TAG and groups with a total TAG content lower than $0.5 \%(\mathrm{w} / \mathrm{w})$ were not considered, as suggested by Bitencourt et al., (2018).

\subsubsection{Diterpenes}

Extraction was performed according to Dias et al., (2014), in duplicate. Samples (0.2 g) were saponified with $2.0 \mathrm{~mL}$ of $2.5 \mathrm{~mol} \cdot \mathrm{L}^{-1}$ potassium hydroxide in ethanol $(96 \% \mathrm{v} / \mathrm{v})$ at $80^{\circ} \mathrm{C}$ for $1 \mathrm{~h}$. For the extraction of the unsaponifiable matter, $2.0 \mathrm{~mL}$ of distilled water and $2.0 \mathrm{~mL}$ of tert-butyl methylether were added. After stirring and centrifugation at room temperature $(3 \mathrm{~min}$ at $3000 \mathrm{rpm}$ ), the organic phase was collected. The last step was repeated 3 times. Distilled water $(2 \mathrm{~mL})$ was added for cleaning, and the organic extract was collected and evaporated to dryness in a water bath $\left(70{ }^{\circ} \mathrm{C}\right)$ and re-suspended in the mobile phase.

The analysis was performed as described by Mori et al., (2016), using UPLC Waters Acquity (Waters, Milford, USA) equipped with an automatic sample injector, solvent quaternary pumping system, column oven, and DAD detector, controlled by the Empower 3 program. Detection was set at $230 \mathrm{~nm}$ (cafestol) and $290 \mathrm{~nm}$ (kahweol). Kinetex C18 column (150 mm $\mathrm{x} 4.6 \mathrm{~mm}, 2.6 \mu \mathrm{m}$ ) (Phenomenex, USA) and volume of injection of $1.4 \mu \mathrm{L}$ were used. Isocratic elution with water: acetonitrile $(45: 55 \mathrm{v} / \mathrm{v})$ at a flow rate of $1.2 \mathrm{~mL} \cdot \mathrm{min}^{-1}$ was performed. The analyses were made in duplicate.

Quantification was performed by external standardization using triplicate 6-point analytical curves $(r \geq 0.999, p<0.001)$, with a limit of quantification (LQ) of $3.2 \mathrm{mg} \cdot 100 \mathrm{~g}^{-1}$ and $3.6 \mathrm{mg} \cdot 100 \mathrm{~g}^{-1}$ for kahweol and cafestol, respectively. The results were expressed as contents of kahweol and cafestol and as total diterpenes $\left(\mathrm{mg} \cdot 100 \mathrm{~g}^{-1}\right)$. 


\subsubsection{Tocopherols}

The tocopherol profile was determined based on the AOCS Ce 8-89 methodology (AOCS, 2014). The oil was directly solubilized in hexane $(1 \%$ w/v). A Lab Alliance LC305 HPLC (Scientific Systems, Inc., USA) with Radpump III pump and LC 305 fluorescence detector and a LiChrospher Si 60 column $(125 \mathrm{~mm}$ x $4 \mathrm{~mm}$, $5 \mu \mathrm{m})$ (Merck, Germany). Fluorescence excitation was set at $325 \mathrm{~nm}$ and emission at $480 \mathrm{~nm}$. Isocratic elution was performed with hexane: ethyl acetate: glacial acetic acid (98: 1.3: $0.7 \% \mathrm{v} /$ $\mathrm{v} / \mathrm{v}$ ), at a flow rate of $1.5 \mathrm{~mL} \cdot \mathrm{min}^{-1}$ and an injection volume of $250 \mu \mathrm{L}$.

Quantification was performed by external standardization using triplicate 6-point analytical curves for each compound $(\alpha, \beta, \gamma$, and $\delta$-tocopherol), with LQ of $0.1 \mathrm{mg} \cdot 100 \mathrm{~g}^{-1}$. The results were expressed as individual tocopherols and as total tocopherol $\left(\mathrm{mg} \cdot 100 \mathrm{~g} \mathrm{~g}^{-1}\right)$.

\subsubsection{Caffeine and chlorogenic acids}

Extraction was performed as described by Carvalho et al., (1990), in triplicate. Coffee oil $(2 \mathrm{~g})$, water $(200 \mathrm{~mL})$, and $\mathrm{MgO}(5 \mathrm{~g})$ were boiled for $45 \mathrm{~min}$. After cooling and filtration, $4 \mathrm{~mL}$ of a sulfuric acid solution (1:9 acid:water) and $20 \mathrm{~mL}$ of chloroform were added to the mixture in a separatory funnel. After stirring, the chloroform layer was transferred to another funnel; the step was repeated five times. A potassium hydroxide solution $1 \%(5 \mathrm{~mL})$ was then added to the extract, and after stirring and phase separation, the extract was filtered and diluted with chloroform.

A chromatographic analysis was performed according to Corso et al., (2016), using a Shimadzu HPLC (Kyoto, Japan) with two pumps (LC-10 AD), a Rheodyne injection valve with $20 \mu \mathrm{L}$ loop, a UV/visible detector (SPD-10 A), CBM-101 interface and Program CLASS-CR10, version 1.2. A Spherisorb ODS1 column $(250 \times$ $4.6 \mathrm{~mm}, 5 \mu \mathrm{m}$ ) (Waters, Ireland) was used, and detection was set at $272 \mathrm{~nm}$ (caffeine) and $320 \mathrm{~nm}$ (chlorogenic acids). A gradient of 5\% acetic acid (A) and acetonitrile (B) solution was used as follows: $0-10 \mathrm{~min}$ : $5 \% \mathrm{~B}$; $10-25 \mathrm{~min}: 13 \% \mathrm{~B}$; 25-35 min: $5 \% \mathrm{~B}$, flow rate $0.5 \mathrm{~mL} \mathrm{~min}{ }^{-1}$. The injections were made in duplicate.

The quantification was performed by external standardization using duplicate 6-point analytical curves $(r \geq 0.999, p<0.001)$. The sum of the compounds was detected at $320 \mathrm{~nm}$, using the
5-CQA as standard, and applied to estimate the total chlorogenic acid content (Corso et al., 2016).

\subsubsection{Volatile compounds}

The analysis was performed by solid-phase micro-extraction followed by quantification in an Agilent 6890 N CG equipped with Agilent 5973 mass spectrometry detector and MSD Chemstation software (Agilent Technologies Inc., USA). Sample preparation and chromatographic conditions were applied according to Kalschne et al., (2018).

The oil was weighed $(1.0 \mathrm{~g})$ in a $20 \mathrm{~mL}$ vial (Agilent, California, USA) immediately sealed with a silicone septum and kept in a water bath $\left(70^{\circ} \mathrm{C}\right)$. After $10 \mathrm{~min}$, the septum was punctured, and a DVB/CAR/PDMS fiber (Sigma Aldrich, USA) was exposed to the headspace for $30 \mathrm{~min}$. After injection, the compounds were heatdesorbed from the fiber (desorption time $10 \mathrm{~min}$ ) and transferred to an Innowax column (60 $\mathrm{m} \mathrm{x}$ $0.32 \mathrm{~mm} \times 0.25 \mu \mathrm{m}$ ) (Agilent, California, USA). Helium was used as carrier gas at $1.3 \mathrm{~mL} \cdot \mathrm{min}^{-1}$ flow rate and the injector temperature was $250{ }^{\circ} \mathrm{C}$. The heating profile started at $40{ }^{\circ} \mathrm{C}$, held $5 \mathrm{~min}$, raised to $60{ }^{\circ} \mathrm{C}$ at $4{ }^{\circ} \mathrm{C} \cdot \mathrm{min}^{-1}$, held at $60{ }^{\circ} \mathrm{C}$ for $5 \mathrm{~min}$ and up to $250{ }^{\circ} \mathrm{C}$ at $8{ }^{\circ} \mathrm{C} \cdot \mathrm{min}^{-1}$, held for $3 \mathrm{~min}$. The mass spectrometer operated at $280{ }^{\circ} \mathrm{C}$ interface temperature, ion source temperature of $230{ }^{\circ} \mathrm{C}$, quadrupole temperature of $150{ }^{\circ} \mathrm{C}$, scanning in a range of $\mathrm{m} / \mathrm{z}$ of 35-400 amu.

The standards $(1 \mathrm{~mL})$ were placed in vials $(20 \mathrm{~mL})$, and injected into the GC-MS using the same extraction technique applied to volatile compounds. Quantification was performed by external standardization using duplicate 6-point analytical curves. Sensory attributes related to each volatile compound, based on those described in literature (Akiyama et al., 2007, Belitz et al., 2009. Dulsat-Serra et al., 2016, Toledo et al., 2016, and Kalschne et al., 2018), were also reported (Table 5).

\section{RESULTS AND DISCUSSION}

Peroxide, acid, iodine and saponification values can be correlated with the stability and quality of oils. They indicate the oxidation degree, stability status, degree of unsaturation, and the relative amount of low fatty acids and high molecular weight (AOCS, 2014). 
Coffee oil showed a peroxide value of $3.208 \mathrm{meq} \cdot \mathrm{kg}^{-1}$ (Table 2). This was higher than that described by Sanches (2016) for roasted Arabica oil stored at a different time and under temperature conditions up to $2.38 \mathrm{meq} \cdot \mathrm{kg}^{-1}$, and Turatti (2001), up to $2.4 \mathrm{meq} \cdot \mathrm{kg}^{-1}$. However, it was still lower than the maximum value $\left(15 \mathrm{meq} \cdot \mathrm{kg}^{-1}\right)$ recommended for cold-pressed oil by the Brazilian regulation (Anvisa, 2005).

TABLE 2. Physico-chemical characterization of roasted Arabica coffee oil.

\begin{tabular}{|c|c|}
\hline Parameters & Oil \\
\hline Peroxide value $\left(\mathrm{meq} \cdot \mathrm{kg}^{-1}\right)^{\mathrm{a}}$ & $3.208 \pm 0.001$ \\
\hline Acid value $\left(\mathrm{mg} \mathrm{KOH} \cdot \mathrm{g}^{-1}\right)^{\mathrm{b}}$ & $7.3 \pm 0.2$ \\
\hline Iodine value $\left(\mathrm{g} \mathrm{I}_{2} .100 \mathrm{~g}^{-1}\right)^{\mathrm{b}}$ & $113.5 \pm 0.3$ \\
\hline Saponification value $\left(\mathrm{mg} \mathrm{KOH} \cdot \mathrm{g}^{-1}\right)^{b}$ & $195.26 \pm 0.08$ \\
\hline Moisture and volatile matter $(\%)^{b}$ & $0.85 \pm 0.05$ \\
\hline Refractive Index ${ }^{\mathrm{b}}$ & $1.4798 \pm 0.0000$ \\
\hline Density $\left(g \cdot \mathrm{mL}^{-1}\right)^{\mathrm{b}}$ & $0.938 \pm 0.002$ \\
\hline Viscosity $\left(\mathrm{mPas} \text { a } 25^{\circ} \mathrm{C}\right)^{\mathrm{b}}$ & $228.7 \pm 0.5$ \\
\hline ABTS $\left(m g \text { Trolox } \cdot m L^{-1}\right)^{a}$ & $12.5 \pm 0.1$ \\
\hline Sun protection factor ${ }^{\mathrm{b}}$ & $9.7 \pm 1.2$ \\
\hline
\end{tabular}

${ }^{\mathrm{a}}$ Means of duplicate \pm standard deviation.

${ }^{\mathrm{b}}$ Means of triplicate \pm standard deviation.

An acid value of $7.3 \mathrm{mg} \mathrm{KOH} \cdot \mathrm{g}^{-1}$ was observed (Table 2), which was lower than that described by Turatti (2001) for roasted coffee oil (8.95 mg $\mathrm{KOH} \mathrm{g}^{-1}$ ) and by Amin et al., (2019) for pumpkin seed oils (from 11.5 to $13.5 \mathrm{mg} \mathrm{NaOH} \cdot \mathrm{g}^{-1}$ ). These values were higher than those defined for coldpressed oils (maximum $4.0 \mathrm{mg} \mathrm{KOH} \cdot \mathrm{g}^{-1}$ ) (Anvisa, 2005). However, no specific regulation can be found for oils that undergo a previous heat treatment such as roasted coffee oil. Furthermore, the literature describes that the roasting process can release acidic compounds, increasing acidity values (Sanches, 2016).

The coffee oil presented an iodine value of 113.50 and a saponification value of $195.26 \mathrm{mg}$ $\mathrm{KOH} \cdot \mathrm{g}^{-1}$ (Table 2). The data were in the range of those reported by Sanches (2016) for roasted Arabica coffee oil: from 92.17 to $114.10 \mathrm{~g}$ $\mathrm{I}_{2} \cdot 100 \mathrm{~g}^{-1}$ and from 192.98 to $233.44 \mathrm{mg} \mathrm{KOH} \cdot \mathrm{g}^{-1}$ for iodine and saponification values, respectively. Values in a similar range were reported by Amin et al., (2019) for pumpkin seed oils: iodine value from 106.6 to $113.2 \mathrm{~g} \mathrm{I}_{2} \cdot 100 \mathrm{~g}^{-1}$ and saponification value from 115.7 to $236.0 \mathrm{mg} \mathrm{KOH} \cdot \mathrm{g}^{-1}$.
The moisture and volatile matter of $0.85 \%$ (Table 2) were attributed to press extraction, since solvent-extracted oils do not contain water. Sanches (2016) reported lower moisture contents (up to $0.2 \%$ ) for roasted coffee oil, although he pointed out that industrial limits varied between 0.30 and $2.00 \%$.

The refractive index can be used as a physical parameter of oil quality. It increases with increasing fatty acid chain length and degree of unsaturation (AOCS, 2014). The coffee oil presented a refractive index of 1.4798 (Table 2), similar to that described by Amin et al., (2019) for pumpkin seed oils (1.5).

Density and viscosity are important parameters for oil processing, since they are determinant for the correct design of the pumping, sedimentation, and filtration steps (Bonnet et al., 2011). The coffee oil had a density of $0.938 \mathrm{~g} \cdot \mathrm{mL}^{-1}$ and a viscosity of $228.7 \mathrm{mPas}$ at $25{ }^{\circ} \mathrm{C}$ (Table 2). Oliveira et al., (2014), evaluating pressed green Arabica coffee oil, reported similar values for density and lower viscosity (from 95 to $127.9 \mathrm{mPas})$. Roasted coffee oil is denser than several other vegetable oils. Stanciu (2019) reported density values from 0.84 to $0.93 \mathrm{~g} \cdot \mathrm{mL}^{-1}$ for soybean, corn, sunflower, grape seed, and olive oils, among others.

Sun protection factor (SPF) and antioxidant capacity are important parameters to evaluate the potential of the oil as an ingredient in food and cosmetics. SPF indicates the relationship between the time of exposure to the sun without generating erythema (redness to the skin) with the use of the product compared to unprotected skin. Consequently, the higher the SPF, the longer the time the skin will be protected against UVB radiation (Wagemaker et al., 2011). For the roasted coffee oil, a SPF of 9.7 and ABTS free radical-scavenging capacity of $12.5 \mathrm{mg}$ Trolox $\mathrm{mL}^{-1}$ (Table 2) were observed. No data was found regarding the antioxidant capacity of coffee oil extracted by pressing. Wagemaker et al., (2011) described a SPF of 1.50 for green Arabica coffee oil, traditionally used in cosmetics. Kaur and Saraf (2010) reported a wide range of SPF for several herbal oils used in cosmetics, from 0.248 (rose oil) to 7.549 (olive oil); besides olive oil, the highest values were found for coconut (7.119), peppermint (6.668), tulsi (6.571) and lemon grass (6.282) oils but they presented lower SPF than roasted coffee oil. Therefore, the efficient protection afforded by roasted coffee oil indicates its potential for use in cosmetic products. 
Roasted coffee oil presented $57.5 \%$ of unsaturated fatty acids (Figure 1-a), indicating susceptibility to lipid oxidation, which highlights the importance of studying chemical parameters related to stability (Table 2). The literature described a wide range for the proportion of saturated, monounsaturated and polyunsaturated fatty acids in coffee oil from 29.45 to $47.3 \%$, 42.72 to $59.17 \%$ and from 4.30 to $17.81 \%$, respectively (Calligaris et al., 2009; Getachew and Chun, 2016; Hurtado-Benavides et al., 2016). These differences may be due to the coffee species used, as well as to the extraction method applied.

Regarding the fatty acid profile, the high proportion of polyunsaturated linoleic acid $(44.42 \%)$ in roasted coffee oil (Figure 1) can be important for the health benefit of the compound ingestion, as it is an essential fatty acid (Spector, 1999). The presence $(9.27 \%$, Figure 1) of monounsaturated oleic acid -an omega-9 fatty acid - is also interesting because of its effect in reducing LDL cholesterol oxidation and as a precursor to the production of most other polyunsaturated fatty acids and hormones (Watkins and German, 2008). On the hand, palmitic acid, the main saturated fatty acid found in the roasted coffee oil (31.59\%, Figure 1), which can increase low-density blood cholesterol levels, is interesting for extended use in several skin product formulations such as soaps and shaving creams and, along with linoleic, stearic and oleic fatty acids, is described as an excellent cosmetic material (Dangarembizi et al., 2015).
The fatty acid profile (Figure 1- b) was similar to that reported in other studies (Turatti, 2001; Oliveira et al., 2005; Calligaris et al., 2009; Raba et al., 2018), since linoleic (L) and palmitic (P) are the main fatty acids, followed by oleic $(\mathrm{O})$ and stearic (S). Some authors have reported higher palmitic acid contents, followed by linoleic acid (Rocha et al., 2013; Hurtado-Benavides et al., 2016). Cornelio-Santiago et al., (2017) and Bitencourt et al., (2018) described a predominance of linoleic, palmitic, oleic, and stearic acids in green coffee oil obtained by supercritical extraction.

Triacylglycerols are the main components of roasted coffee oil. It was estimated that the main TAGs in the roasted coffee oil were PLL (18.7\%), PLP (13.3\%), LLL (8.8\%), PLO (7.8\%), SLP $(6.3 \%)$ and OLL (5.5\%) (Table 3).

González et al., (2001) reported higher contents in PLL (20.1 to $31.5 \%$ ) and PLP (15.8 to $28.9 \%$ ) for Soxhlet-extracted roasted Arabica coffee oil. For green coffee oil, Cornelio-Santiago et al., (2017) reported SLP (12.9\%), PLL (12.3\%), and PLP (11.6\%) as the main TAGs, while Bitencourt et al., (2018) highlighted the high PLP (22.9\%) and PLL $(22.6 \%)$ contents.

The profile of fatty acid and triacylglycerols observed for the studied roasted coffee oil (Figure 1 and Table 3) was similar to that described in the literature for oils obtained by different extraction methods and green coffee oil, showing the potential use of pressed roasted coffee oil. (a)

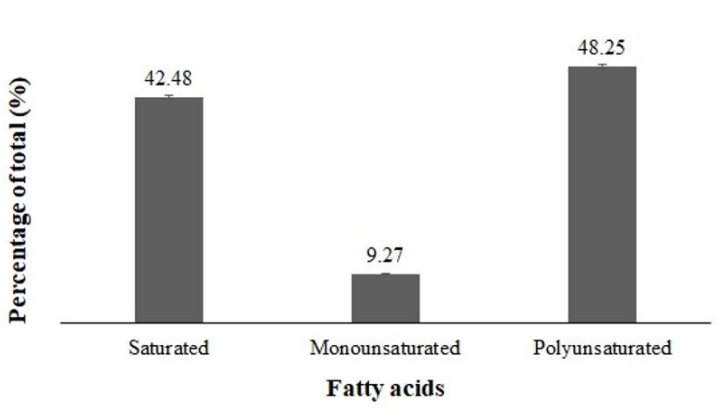

(b)

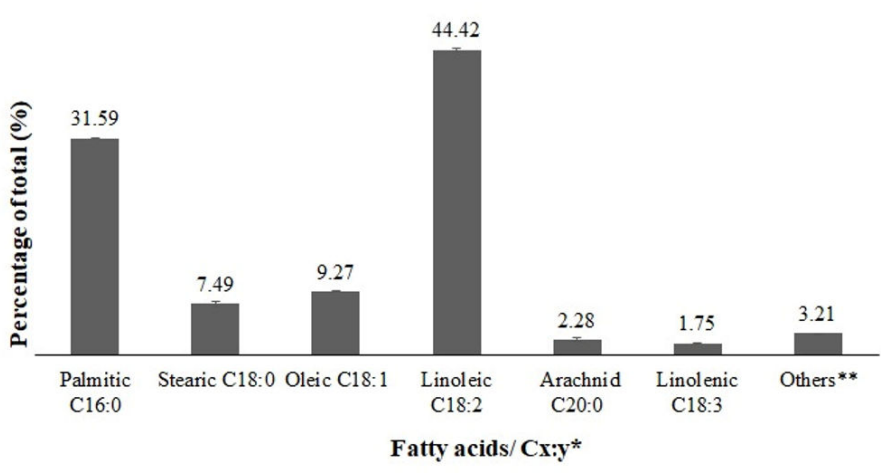

Means of triplicate; error bars: standard deviation

*Cx:y where $\mathrm{Cx}=$ number of carbons and $\mathrm{y}=$ number of double bonds.

**Others: Myristic, Margaric, n-Heneicosanoic, Eicosadienoic, Behenic, Timnodonic, Adrenic and Clupanodonic acids presented in contents up to $1 \%$.

FIGURE 1. Fatty acids of roasted Arabica coffee oil. (a) Percentage of saturated, monounsaturated and polyunsaturated fatty acids. (b) Fatty acid profile. 
TABLE 3. Hypothetical triacylglycerol profile of roasted Arabica coffee oil.

\begin{tabular}{ccc}
\hline Triacylglycerols $^{\mathbf{a}}$ & $\mathbf{C x}^{\mathbf{y}} \mathbf{y}^{\mathbf{b}}$ & Percentage of total (\%) $^{\mathbf{c}}$ \\
\hline PPP & $48: 0$ & $3.16 \pm 0.13$ \\
SPP & $50: 0$ & $2.25 \pm 0.04$ \\
POP & $50: 1$ & $2.78 \pm 0.06$ \\
PLP & $50: 2$ & $13.30 \pm 0.29$ \\
SOP & $52: 1$ & $1.32 \pm 0.03$ \\
SLP & $52: 2$ & $6.31 \pm 0.03$ \\
PLO & $52: 3$ & $7.80 \pm 0.06$ \\
PLL & $52: 4$ & $18.69 \pm 0.19$ \\
PLnL & $52: 5$ & $1.46 \pm 0.06$ \\
PLA & $54: 2$ & $1.88 \pm 0.03$ \\
SLO & $54: 3$ & $1.85 \pm 0.06$ \\
SLL & $54: 4$ & $4.44 \pm 0.11$ \\
OLO & $54: 4$ & $1.14 \pm 0.04$ \\
OLL & $54: 5$ & $5.48 \pm 0.13$ \\
LLL & $54: 6$ & $8.75 \pm 0.21$ \\
LLnL & $54: 7$ & $1.03 \pm 0.04$ \\
ALL & $56: 4$ & $1.32 \pm 0.05$ \\
Others & & $8.25 \pm 1.08$ \\
\hline
\end{tabular}

${ }^{\mathrm{a}}$ Fatty acids: Arachnid (A), Adrenic (Ad), Behenic (Be), Clupanodonic (Cp), Linoleic (L), Linolenic (Ln), Oleic (O), Palmitic (P), Stearic (S), Timnodonic $(\mathrm{Tm}) \cdot{ }^{\mathrm{b}} \mathrm{Cx}$ : y where $\mathrm{Cx}=$ number of carbons and $\mathrm{y}=$ number of double bonds. ${ }^{\mathrm{d}} \mathrm{PLnP}$ (50: 3), SPS (52: 0), PAP (52:0), POO (52: 2), SLS (54: 2), PTmL (54: 7), BeLP (56:2), ALO (56: 3), PAdL (56: 6), PCpL (56: 7) presented in contents up to $1 \%$.'Means of triplicate \pm standard deviation.

Diterpenes, the major components of UM, correspond to 86 to $88 \%$ of the UM for Arabica coffee (Pacetti et al., 2015), and their contents remained stable during the roasting process (Dias et al., 2014). Kahweol and cafestol are the main diterpenes in coffee and produced only by plants of the Coffea genus (Dias et al., 2014). They are of interest due to their anticarcinogenic, antioxidant, anti-inflammatory, and hepatoprotective activities, and also to their skin hydration and sun protection effects (Kim et al., 2009; Muriel and Arauz, 2010) although cafestol is also related to an increase in serum cholesterol levels (Speer and Kölling-Speer, 2006). The coffee oil presented a total diterpenes content of $3720 \mathrm{mg} \cdot 100 \mathrm{~g}^{-1}$, with 1980 and $1740 \mathrm{mg} 100 \mathrm{~g}^{-1}$ of kahweol and cafestol, respectively (Table 4). Oliveira et al., (2014) and Bitencourt et al., (2018) reported higher efficiency of supercritical extraction of green coffee oil diterpenes compared to pressing. It was also observed that the kahweol content (Table 4) was comparable to that reported by Bitencourt et al., (2018) (up to $1500 \mathrm{mg} \cdot 100 \mathrm{~g}^{-1}$ ) for green coffee oil using supercritical extraction.

TABLE 4. Unsaponifiable matter and hydrosoluble compounds of roasted Arabica coffee oil.

\begin{tabular}{ccc}
\hline & Compounds & $\begin{array}{c}\text { Content } \\
\left(\mathbf{m g} \cdot \mathbf{1 0 0 g ^ { - 1 }}\right)\end{array}$ \\
\hline Diterpenes $^{\mathrm{a}}$ & Kahweol & $1980 \pm 50$ \\
& Cafestol & $1740 \pm 60$ \\
& Total & 3720 \\
\hline Tocopherols $^{\mathrm{b}}$ & $\alpha$ & $30.350 \pm 0.250$ \\
& $\beta$ & $881.123 \pm 17.080$ \\
& $\delta$ & $2.226 \pm 0.004$ \\
\hline Hydrosoluble & & 913 \\
\hline & Cotal & $350 \pm 10$ \\
\hline${ }^{\mathrm{a}}$ Means of duplicate of extraction \pm standard deviation. \\
${ }^{\mathrm{b}}$ Means of triplicate \pm standard deviation.
\end{tabular}

In the UM, the presence of tocopherols also stands out, both for vitamin activity and antioxidant effect, which contributes to the stabilization of cell membranes which protect other bioactive compounds. The main component was $\beta$-tocopherol ( $97 \%$ of the total), followed by $\alpha$ and $\delta$ isomers; $\gamma$-tocopherol was absent (below the LD of $0.07 \mathrm{mg} \cdot 100 \mathrm{~g}^{-1}$ ) (Table 4). Thus, a high total tocopherol content of $913 \mathrm{mg} \cdot 100 \mathrm{~g}^{-1}$ was observed, corresponding to $271 \mathrm{mg}$ of vitamin $\mathrm{E}$ (expressed as $\alpha$-tocopherol) $100 \mathrm{~g}^{-1}$ or $298 \mathrm{IU}$ of vitamin $\mathrm{E} \cdot 100 \mathrm{~g}^{-1}$.

In the literature, no consensus is found on the tocopherol profile of roasted Arabica coffee oil. González et al., (2001) reported the $\beta$-isomer (from 9.4 to $16.1 \mathrm{mg} \cdot 100 \mathrm{~g}^{-1}$ ) as the major one, followed by $\gamma$ and $\alpha$-tocopherol (5.9 to 9.5 and 2.1 to $\left.3.4 \mathrm{mg} \cdot 100 \mathrm{~g}^{-1}\right)$ and the absence of $\delta$-tocopherol. Ribeiro (2015) reported a higher $\gamma$-tocopherol content $\left(182 \mathrm{mg} \cdot 100 \mathrm{~g}^{-1}\right)$, followed by $\beta, \delta$, and $\alpha$ isomers $\left(94,25\right.$, and $1 \mathrm{mg} \cdot 100 \mathrm{~g}^{-1}$, respectively). It should be noted that, besides the difference in the isomer profile, those authors reported lower total tocopherol contents than those obtained in this study, probably due to the high temperature used in Soxhlet extraction. For pressed green coffee oil, contents of 13.3 and $34.7 \mathrm{mg} \cdot 100 \mathrm{~g}^{-1}$ of $\alpha$ and $\beta$ tocopherol, respectively, were reported (Bitencourt et al., 2018). Therefore, the efficient extraction of the UM compounds of the roasted coffee by pressing can stand out. 
As previously discussed, as roasted coffee was pressed, it was also possible to extract some hydrosoluble compounds of known antioxidant effects such as caffeine and chlorogenic acids. The coffee oil presented $350 \mathrm{mg} \cdot 100 \mathrm{~g}^{-1}$ of caffeine and $10.71 \mathrm{mg} \cdot 100 \mathrm{~g}^{-1}$ of total chlorogenic acids (Table 4). The higher caffeine extraction was attributed to its lower molecular weight (194.194 $\left.\mathrm{g} \cdot \mathrm{mol}^{-1}\right)$, and higher water solubility (22 $\left.\mathrm{g} \cdot \mathrm{L}^{-1}\right)$ (Pubchem, 2018) compared to chlorogenic acids.

Similar caffeine contents, from 320 to $340 \mathrm{mg} \cdot 100 \mathrm{~g}^{-1}$, were reported by Sanches (2016) for roasted Arabica coffee oil obtained by pressing. Oliveira et al., (2014) highlighted a higher efficiency of the supercritical extraction process with caffeine contents from 260 to $1650 \mathrm{mg} \cdot 100 \mathrm{~g}^{-1}$ in green Arabica coffee oil.

No data on chlorogenic acid content in roasted coffee oil were found. For green coffee oil, Bitencourt et al., (2018) reported $8.8 \mathrm{mg}$ $\mathrm{GAE} \cdot 100 \mathrm{~g}^{-1}$ using pressing extraction, and Oliveira et al., (2014) reported a wider range of values ( 0 to $\left.262 \mathrm{mg} \mathrm{GAE} \cdot 100 \mathrm{~g}^{-1}\right)$ depending on supercritical extraction conditions. It should be considered, however, that the Folin-Ciocalteu estimation is not specific for phenolic compounds, and the response may also be due to other reducing compounds.

The presence of these bioactive compounds (Table 4) may also be associated with the antioxidant capacity and SPF characteristics observed for roasted coffee oil (Table 2).

Thirty-five volatile compounds of different classes (carboxylic acids, ketones, furans, thiols, pyrazines, phenols, pyridines, aldehydes, terpenes, alcohols, sulfur compounds, and thiazoles) were quantified in the oil (Table 5), several of them being described as typical of roasted coffee aroma (Akiyama et al., 2007; López-Galilea et al., 2006).

For roasted Arabica coffee oil, Getachew and Chun (2016) described the presence of aldehydes, ketones, furans, pyrroles, pyrazines, pyridines, and phenolic compounds (24 volatile compounds), and Hurtado-Benavides et al., (2016) reported a greater number of compounds (41 volatiles), mainly furans and pyrazines, in products obtained by supercritical extraction. In pressed oil, Oliveira et al., (2005) identified 32 volatile compounds, including hydrocarbons, pyrazines, furans, and ketones.

The volatile compounds found in higher contents belong to carboxylic acids, ketones, furans, and thiol classes. We highlight the acetic acid, with a negative impact on the aroma profile, and maltol, 2-furfurylthiol, furfuryl acetate, and 2,6-dimethylpyrazine, which presented potential positive aroma characteristics. The pyrazine class contained the highest number of volatile compounds, and the lowest number of compounds was observed in the classes of terpenes, alcohols, sulfur compounds, and thiazoles (Table 5). The volatile compounds in the roasted coffee oil can be formed by the thermal degradation of carbohydrates, amino acids, ascorbic acid, lipids, esters, and the auto-oxidation of aldehydes and ketones during the roasting process (Buffo and Cardelli-Freire, 2004).

Carboxylic acids account for a high proportion of roasted coffee's volatile fraction (Kalschneet al., 2018). Volatile acids present characteristic odors, and acetic acid is present in high contents in the roasted coffee oil $\left(1287.63 \mathrm{ng} \cdot \mathrm{g}^{-1}\right)$ (Table 5), is related to vinegar odor (Belitz et al., 2009).

Ketones are also abundant in roasted coffee (Toledo et al., 2016), presenting aromas such as fruit, butter, mushroom, mold, caramel, and tea (López-Galilea et al., 2006; Akiyama et al., 2007). Maltol, present in higher contents $\left(835.94 \mathrm{ng} \cdot \mathrm{g}^{-1}\right)$ (Table 5), presents a caramel odor (Belitz et al., 2009).

Furans are described as the main chemical class found in Arabica coffee, followed by pyrazines, pyridines, and pyrroles (Toledo et al., 2016). They can give an aroma of roasted malt, sweet, grass, fruits, burnt, burnt sugar, and others (LópezGalilea et al., 2006; Akiyama et al., 2007, Nascimento et al., 2007; Belitz et al., 2009). The furan found in higher contents in the roasted coffee oil was furfuryl acetate $\left(539.88 \mathrm{ng} \cdot \mathrm{g}^{-1}\right)$ (Table 5), which has a floral and fruity odor (Nascimento et al., 2007).

Although presented in lower contents, thiols and pyrazines have a significant impact on the characteristic aroma and flavor of coffee brews. Thiols are related to aromas of roasted, fresh coffee, roasted meat, and nuts, among others (Dulsat-Serra et al., 2016). A high content in 2-furfurylthiol in the oil (727.16 $\mathrm{ng} \cdot \mathrm{g}^{-1}$ ) (Table 5) was observed, which is a key aromatic compound in roasted coffee products (Toledo et al., 2016, Nascimento et al., 2007; Belitz et al., 2009). Pyrazines are described as presenting aromas of nut, earth, roasted and grass (Czerny and Grosch, 2000; Akiyama et al., 2007; Toledo et al., 2016). 
10 - B.R. Böger et al.

TABLE 5. Profile of volatile compounds of roasted Arabica coffee oil.

\begin{tabular}{|c|c|c|c|}
\hline Sensory Group ${ }^{a}$ & Volatile Compound / Class & Compound content $\left(\mathbf{n g} \cdot \mathrm{g}^{-1}\right)^{\mathrm{b}}$ & Class content (ng $\left.\cdot \mathbf{g}^{-1}\right)$ \\
\hline \multicolumn{4}{|c|}{ Carboxylic acids } \\
\hline Fermented & Isovaleric acid & 68.82 & \multirow{3}{*}{1422.01} \\
\hline Chemist / Pungent & Acetic acid & 1287.63 & \\
\hline Vegetable / Herbaceous & Propanoic acid & 65.56 & \\
\hline \multicolumn{4}{|c|}{ Ketones } \\
\hline Sweet, Burned & 2,3-Butanedione & 1.58 & \multirow{4}{*}{869.74} \\
\hline Sweet, Burned & 2,3-Pentanedione & 0.12 & \\
\hline Sweet, Burned & Acetoin & 32.10 & \\
\hline Sweet, Burned & Maltol & 835.94 & \\
\hline \multicolumn{4}{|c|}{ Furans } \\
\hline Floral & Furfuryl acetate & 539.88 & \multirow{3}{*}{741.87} \\
\hline Vegetable & Furfural & 199.90 & \\
\hline \multirow[t]{2}{*}{ Sweet, Burned } & Furaneol & 2.09 & \\
\hline & Thiols & & \multirow{3}{*}{727.17} \\
\hline Burned (Coffee) & $\begin{array}{c}\text { 2-Furfurylthiol } \\
\text { (Fufurylmercaptane) }\end{array}$ & 727.16 & \\
\hline \multirow[t]{2}{*}{ Putrid } & Methanethiol & 0.01 & \\
\hline & Pyrazines & & \multirow{9}{*}{560.29} \\
\hline Seasoning & 2,3-Diethyl-5-methylpyrazine & 1.05 & \\
\hline Nuts & 2,5-Dimethylpyrazine & 114.29 & \\
\hline Nuts & 2,3-Dimethylpyrazine & 39.59 & \\
\hline- & 2-Isobutyl-3-methylpyrazine & 0.27 & \\
\hline- & 2-Isobutyl-3-methoxypyrazine & 0.31 & \\
\hline- & 2-Acetyl-3,5-dimethylpyrazine & 6.00 & \\
\hline Burned (Coffee) & 2,6-Dimethylpyrazine & 361.41 & \\
\hline \multirow[t]{2}{*}{ Moldy / Earth } & Pyrazine & 37.37 & \\
\hline & Phenols & & \multirow{6}{*}{491.95} \\
\hline Chemical & Guaiacol & 113.54 & \\
\hline Sweet / Vanilla & Vanillin & 3.31 & \\
\hline Smoked & 4-Ethylguaiacol & 89.14 & \\
\hline Smoked & 4-Vinylguaiacol & 285.15 & \\
\hline \multirow[t]{2}{*}{ Smoked } & Cis-isoeugenol & 0.81 & \\
\hline & Pyridines & & \multirow{3}{*}{388.84} \\
\hline Burned (Coffee) & Pyridine & 386.92 & \\
\hline \multirow[t]{2}{*}{ Burned (Coffee) } & 2-Acetylpyridine & 1.92 & \\
\hline & Aldehydes & & \multirow{3}{*}{113.83} \\
\hline Pungent & Acetaldehyde (ethanal) & 87.88 & \\
\hline $\begin{array}{l}\text { Pungent } \\
\text { Frutal }\end{array}$ & 3-Methylbutanal & 25.95 & \\
\hline \multirow{3}{*}{ Vegetable } & Terpenes & & \\
\hline & Linalool & 4.02 & 4.02 \\
\hline & Alcohols & & \\
\hline Sweet, Burned & Benzyl alcohol & 1.52 & \multirow{2}{*}{3.71} \\
\hline Smoked & Phenylethyl alcohol & 2.19 & \\
\hline \multicolumn{4}{|c|}{ Sulfur compounds } \\
\hline Putrid & Dimethyldisulfite & 3.27 & 3.27 \\
\hline \multicolumn{4}{|c|}{ Thiazoles } \\
\hline Burned (Coffee) & 4,5-Dimethylthiazole & 0.48 & \multirow{2}{*}{1.11} \\
\hline Moldy / Earth & 4-Methylthiazole & 0.63 & \\
\hline
\end{tabular}

Grasas y Aceites 72 (1), January-March 2021, e394. ISSN-L: 0017-3495. https://doi.org/10.3989/gya.1144192 
The main pyrazine identified in the roasted coffee oil was 2,6-dimethylpyrazine (361.41 $\mathrm{ng} \cdot \mathrm{g}^{-1}$ ), which presents a characteristic aroma of burnt coffee and roasted cocoa/nut (Nascimento et al., 2007).

\section{CONCLUSIONS}

Roasted coffee oil proved to be a high quality product due to its low peroxide and acid values, significant contents in tocopherols and diterpenes, in addition to the presence of caffeine and chlorogenic acids, resulting in high antioxidant capacity. The roasted oil presented a high sun protection factor effect (compared to green coffee oil and others herbal oils), and the profile of fatty acids and triacylglycerols was similar to that described in the literature for green coffee oil. In the complex profile of volatiles, thirty-five compounds of different classes were identified, with pyrazines and furfurylthiol as the predominant ones. These properties show that roasted coffee oil has good potential for use in food and cosmetics.

\section{ACKNOWLEDGMENTS}

The authors wish to thank CNPq and CAPES for financial support.

\section{REFERENCES}

Akiyama M, Murakami K, Ikeda M, Iwatsuki K, Wada A, Tokuno K, Onishi M, Iwabuchi $\mathrm{H}$. 2007. Analysis of the headspace volatiles of freshly brewed arabica coffee using solidphase microextraction. J. Food Sci. 72, 388-396. https://doi.org/10.1111/j.1750-3841. 2007.00447.x

Amin MZ, Islam T, Mostofa F, Uddin MJ, Rahman MM, Satter MA. 2019. Comparative assessment of the physicochemical and biochemical properties of native and hybrid varieties of pumpkin seed and seed oil (Cucurbita maxima Linn.). Heliyon 5, 1-6. https://doi.org/10.1016/j.heliyon.2019.e02994

Anvisa. 2005. Agência Nacional de Vigilância Sanitária (ANVISA). RDC n ${ }^{\circ} 270$, de 22 de setembro de 2005. Regulamento técnico para óleos vegetais, gorduras vegetais e creme vegetal. Diário Oficial [da] República Federativa do Brasil, Brasília, DF, n. 184, Seção 1. p.372.
AOCS. 2014. Official methods and recommended practices of the American Oil Chemist's Society. Official Method CE 8-89. Champaign: AOCS Press. Vol 1 and 2.

Belitz HD, Grosch W, Schieberle P. 2009. Food Chemistry. 4th, Springer, Berlin.

Bitencourt RG, Ferreira NJ, Oliveira AL, Cabral FA, Meirelles AJA. 2018. High pressure phase equilibrium of the crude green coffee oil - $\mathrm{CO} 2$ - ethanol system and the oil bioactive compounds. J. Supercrit. Fluids 133, 49-57. https://doi.org/10.1016/j.supflu.2017.09.017

Bonnet JP, Devesvre L, Artaud J, Moulin P. 2011. Dynamic viscosity of olive oil as a function of composition and temperature: A first approach. Eur. J. Lipid Sci. Technol. 113, 1019-1025. https://doi.org/10.1002/ejlt.201000363

Budryn G, Nebesny E, Zyzelewicz D, Oracz J, Miśkiewicz K, Rosicka-Kaczmarek J. 2012. Influence of roasting conditions on fatty acids and oxidative changes of Robusta coffee oil. Eur. J. Lipid Sci. Technol. 114, 1052-1061. https://doi.org/10.1002/ejlt.201100324

Buffo RA, Cardelli-Freire C. 2004. Coffee flavour: An overview. Flavour Fragr. J. 19, 99-104. https://doi.org/10.1002/ffj.1325

Calligaris S, Munari M, Arrighetti G, Barba, L, 2009. Insights into the physicochemical properties of coffee oil. Eur. J. Lipid Sci. Technol. 111, 1270-1277. https://doi.org/10. 1002/ejlt.200900042

Carvalho CRL, Mantovani DMB, Carvalho PRN, Moraes RMM. 1990. Análises químicas de alimentos. Manual Técnico. Campinas: ITAL, $121 \mathrm{p}$.

Cornelio-Santiago HP, Gonçalves CB, Oliveira NA, Oliveira AL. 2017. Supercritical CO2 extraction of oil from green coffee beans: Solubility, triacylglycerol composition, thermophysical properties and thermodynamic modelling. J. Supercrit. Fluids 128, 386-394. https://doi.org/10.1016/j.supflu.2017.05.030

Corso MP, Vignoli JA, Benassi MT. 2016. Development of an instant coffee enriched with chlorogenic acids. J. Food Sci. Technol. 53, 1380-1388. https://doi.org/10.1007/s13197 $-015-2163-y$

Czerny M, Grosch W. 2000. Potent odorants of raw Arabica coffee. Their changes during roasting. J. Agric. Food Chem. 48, 868-872. https://doi.org/10.1021/jf990609n

Dangarembizi R, Chivandi E, Dawood S, Erlwanger KH, Gundidza M, Magwa ML, Muredzi P, Samie A. 2015. The fatty acid 
composition and physicochemical properties of theunderutilised Cassia abbreviata seed oil. Pak J. Pharm. Sci. 28, 1005-1008.

Dias RCE, Faria-Machado AF, Mercadante AZ, Bragagnolo N, Benassi MT. 2014. Roasting process affects the profile of diterpenes in coffee. Eur. Food Res. Technol. 239, 961-970. https://doi.org/10.1007/s00217-014-2293-x

Dulsat-Serra N, Quintanilla-Casas B, Vichi S. 2016. Volatile thiols in coffee: A review on their formation, degradation, assessment and influence on coffee sensory quality. Food Res. Int. 89, 982-988. https://doi.org/10.1016/j.fo odres.2016.02.008

Getachew AT, Chun BS. 2016. Optimization of coffee oil flavor encapsulation using response surface methodology. LWT - Food Sci. Technol. 70, 126-134. https://doi.org/10.1016/ j.lwt.2016.02.025

González AG, Pablos F, Martín MJ, LeónCamacho M, Valdenebro MS. 2001. HPLC analysis of tocopherols and triglycerides in coffee and their use as authentication parameters. Food Chem. 73, 93-101. https:// doi.org/10.1016/S0308-8146(00)00282-X

Guercia E, Berti F, Navarini L, Demitri N, Forzato C. 2016. Isolation and characterization of major diterpenes from C. canephora roasted coffee oil. Tetrahedron: Asymmetry 27, 649-656. https://doi.org/10.1016/j.tetasy.201 6.06 .008

Hurtado-Benavides A, Dorado DA, SánchezCamargo ADP. 2016. Study of the fatty acid profile and the aroma composition of oil obtained from roasted Colombian coffee beans by supercritical fluid extraction. J. Supercrit. Fluids 113, 44-52. https://doi.org/10.1016/ j.supflu.2016.03.008

Ico. 2019. International Coffee Organization. Coffee Market Report - December 2019. Available in: <http://www.ico.org/documents/ cy2019-20/cmr-1219-p.pdf $>$ Access on 15 January 2020.

ISO. 1978. International Organization for Standardization. ISO 5509: Animal and Vegetable Fats and Oils: Preparation of Methyl Esters of Fatty Acids. London: International Organization for Standardization.

Kalschne DL, Viegas MC, Conti AJ, Corso MP, Benassi MT. 2018. Steam pressure treatment of defective Coffea canephora beans improves the volatile profile and sensory acceptance of roasted coffee blends. Food Res. Int. 105,
393-402. https://doi.org/10.1016/j.foodres.201 7.11.017

Kaur CD, Saraf S. 2010. In vitro sun protection factor determination of herbal oils used in cosmetics. Pharmacognosy Res. 2, 22-25. https://doi.org/10.4103/0974-8490.60586

Kim HG, Hwang YP, Jeong HG. 2009. Kahweol blocks STAT3 phosphorylation and induces apoptosis in human lung adenocarcinoma A549 cells. Toxicol. Lett. 187, 28-34. https:// doi.org/10.1016/j.toxlet.2009.01.022

López-Galilea I, Fournier N, Cid C, Guichard E. 2006. Changes in headspace volatile concentrations of coffee brews caused by the roasting process and the brewing procedure. $J$. Agric. Food Chem. 54, 8560-8566. https:// doi.org/10.1021/jf061178t

Mori ALB, Kalschne DL, Ferrão MAG, Fonseca AFA, Ferrão RG, Benassi MT. 2016. Diterpenes in Coffea canephora. J. Food Compos. Anal. 52, 52-57. https://doi.org/ 10.1016/j.jfca.2016.08.004

Muriel P, Arauz J. 2010. Coffee and Liver Disease. Fitoterapia 81, 297-305. https:// doi.org/10.1016/j.jceh.2016.02.003

Nascimento EA, Aquino FJT, Nascimento PM, Chang R, Morais SAL. 2007. Volatiles compounds and potent odorants of conilon coffee in different degrees of roasting. Rev. Ciência Eng. 16, 23-30.

PubChem. 2018. National Center for Biotechnology Information (NCBI). Available in: $\quad<$ https://pubchem.ncbi.nlm.nih.gov/> Access on 13 May. 2019.

Oliveira AL, Cruz PM, Eberlin MN, Cabral FA. 2005. Brazilian roasted coffee oil obtained by mechanical expelling: compositional analysis by GC-MS. Ciência e Tecnol. Aliment. 25, 677-682. https://doi.org/10.1590/S0101-2061 2005000400009

Oliveira PMA, Almeida RH, Oliveira NA, Bostyn S, Gonçalves CB, Oliveira AL. 2014. Enrichment of diterpenes in green coffee oil using supercritical fluid extraction Characterization and comparison with green coffee oil from pressing. J. Supercrit. Fluids 95, 137-145. https://doi.org/10.1016/j.supflu. 2014.08.016

Pacetti D, Lucci P, Frega NG. 2015. Unsaponifiable matter of coffee, in Preedy, VR, 1st Edition. Coffee in Health and Disease Prevention. London, England: Academic Press,119- 127. 
Plataforma Lames. 2019. Available in: <http:// projetos.extras.ufg.br/plames/>Access on 15 January. 2020.

Raba DN, Chambre DR, Copolovici DM, Moldovan C, Copolovici LO. 2018. The influence of high-temperature heating on composition and thermo-oxidative stability of the oil extracted from Arabica coffee beans. PLoS One 13, 1-13. https://doi.org/10.1371/ journal.pone.0200314

Ribeiro, JM. 2015. Estudo da composição química $\mathrm{e}$ das atividades antioxidante $\mathrm{e}$ antibacteriana dos óleos extraídos dos grãos de café (Coffea arabica) cru e torrado. Dissertação, 72f. Mestrado em Química Orgânica. Universidade Federal dos Vales do Jequitinhonha e Mucuri, Diamantina, 2015. Available in: <http://acervo.ufvjm.edu.br/jspui/ bitstream/1/817/1/juliana martins ribeiro.pdf> Access on 15 January 2020.

Rocha CC, Reis C, Chaves ARM. 2013. Caracterização qualitativa de ácidos graxos como componentes dos óleos de grão de café verde, café torrado e borra de café, in: VIII Simpósio de pesquisa dos cafés do Brasil. Salvador-BA, 1-5.

Sanches MZ. 2016. Avaliação das características fisico-químicas e sensoriais de óleo de café torrado (Coffea arabica) durante armazenamento em diferentes temperaturas. Dissertação, 68 f. Mestrado em Tecnologia de Alimentos. Universidade Tecnológica Federal do Paraná, Londrina, 2016. Available in:<http://repositorio.utfpr.edu.br/jspui/bitstrea
m/1/2236/1/LD_PPGTAL_M_Sanches $\% 2 c \% 2$ 0Marcelo\%20Zuchi_2016.pdf $>$ Access on 15 January. 2020

Spector AA. 1999. Essentiality of fatty acids. Lipids 34, 1-3. https://doi.org/10.1007/bf025 62220

Speer K, Kölling-Speer I. 2006. The lipid fraction of the coffee bean. Brazilian J. Plant Physiol. 18, 201-216. https://doi.org/10.1590/S1677-04 202006000100014

Stanciu I. 2019. A new mathematical model for the viscosity of vegetable oils based on freely sliding molecules. Grasas Aceites 70 (3), e318. https://doi.org/10.3989/gya.0824182

Toledo PRAB, Pezza L, Pezza HR, Toci AT. 2016. Relationship between the different aspects related to coffee quality and their volatile compounds. Compr. Rev. Food Sci. Food Saf. 15, 705-719. https://doi.org/10.11 11/1541-4337.12205

Turatti JM. 2001. Extração e caracterização de óleo de café, in: II Simpósio de pesquisa dos cafés do Brasil. 1-15.

Wagemaker TAL, Carvalho CRL, Maia NB, Baggio SR, Guerreiro Filho O. 2011. Sun protection factor, content and composition of lipid fraction of green coffee beans. Ind. Crops Prod. 33, 469-473. https://doi.org/10.1016/ j.indcrop. 2010.10 .026

Watkins SM, German JB. 2008. Unsaturated fatty acids, in Akoh CC, Min DB (Ed.) Food Lipids - Chemistry, Nutrition, and Biotechnology. 3ed, CRC Press, Boca Raton, 514-530. 